\title{
Taxon- and senescence-specific fluorescence of colored leaves from the Pliocene Willershausen Lagerstätte, Germany
}

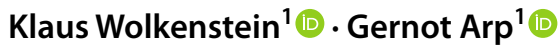

Received: 26 August 2020 / Accepted: 30 November 2020 / Published online: 10 February 2021

(c) The Author(s) 2021

\begin{abstract}
UV-light-induced fluorescence is widely used in the study of coal macerals and palynological samples, but to date has not been described in great detail for plant macrofossils. Here, we report the characteristics of bright UV-light-induced fluorescence of various fossil angiosperm leaf taxa from the Upper Pliocene of Willershausen, Lower Saxony, Germany. The fluorescence is exceptional, since different fluorescence colors ranging from green to yellow to red can be observed and fluorescence properties are found to be related to genera. Using confocal laser scanning microscopy, fluorescence was studied in detail and emission spectra were obtained that allowed to differentiate broad groups of fluorophores. Fluorescence emissions attributed to chlorophyll degradation products demonstrate that fluorescence can be used as an indicator for exceptional chemical preservation of leaf fossils. Comparison with present-day senescing plants suggests that the fluorescence differences in the fossil leaves are mainly caused by taxon-specific degeneration of organic compounds during senescence. The occurrence of various leaf taxa with different fluorescence properties, preserved under identical conditions of fossilization, indicate that diagenesis was not crucial for the differences in leaf fluorescence.
\end{abstract}

Keywords Fossil leaves $\cdot$ Preservation $\cdot$ Fluorescence $\cdot$ Confocal laser scanning microscopy $\cdot$ Pliocene $\cdot$ Willershausen

\section{Introduction}

UV-light-induced fluorescence is commonly observed in fossil plant remains. It is widely used in the analysis of coal macerals and palynological samples, where fluorescence properties (i.e., color, intensity) can provide information on thermal maturity (Van Gijzel 1967; Teichmüller and Wolf 1977). In plant macrofossils, fluorescence microscopy has mainly been applied to study micromorphological details of cuticles such as stomata (e.g., Friedrich and Schaarschmidt 1977; Schaarschmidt 1982; Kerp 1990; Meyer 2003; Kerp and Bomfleur 2011; Elgorriaga et al. 2019), however, little information has been provided concerning fluorescence color, spectroscopic analysis of emitted light, or possible fluorophores. Only Van Gijzel (1977) reported fluorescence

Handling Editor: Joachim Reitner.

Klaus Wolkenstein

klaus.wolkenstein@uni-goettingen.de

1 Department of Geobiology, Geoscience Centre, University of Göttingen, Goldschmidtstraße 3, 37077 Göttingen, Germany parameters (e.g., emission maxima) of several fossil plant remains. Wilde (1989) gave more detailed information on the fluorescence properties of the leaf remains from Messel (Eocene, Germany), describing yellow to green fluorescence of several species. He also mentioned that fluorescence is helpful to better differentiate between individual species (e.g., Daphnogene species). Furthermore, only relatively few color images showing fluorescence of plant macrofossils can be found in the literature, especially those displaying larger parts or even complete leaves (e.g., Schaarschmidt 1988; Kerp and Bomfleur 2011; Elgorriaga et al. 2019).

Because striking differences in the color of fluorescence are typically not observed in the plant remains of a single locality, it was surprising to discover that many well-preserved angiosperm leaves from the Pliocene of the Willershausen fossil Lagerstätte in Germany show bright and especially colorful fluorescence under UV-light. In particular, since Straus (1930) noted that he could not observe fluorescence of leaves from Willershausen when viewed under UV-light, and Friedrich and Schaarschmidt (1988) mentioned only the fluorescence of stomata of two Quercus leaves from this locality. 
Willershausen represents one of the taxonomically richest Pliocene assemblages in Europe (Mai 1995; Ferguson and Knobloch 1998), and is well known for the exceptional preservation of plant and animal fossils. Plant and arthropod cuticles are well preserved (Straus 1969; Briggs et al. 1998) and many vertebrate fossils show preservation of soft parts (Westphal 1967; Rietschel and Storch 1974), in some cases even including pigmentation (Spinar 1980). The preservation of leaves from Willershausen is outstanding in showing color preservation (Schmidt 1939; Straus 1952, 1969, 1977; Knobloch 1998; Ferguson and Knobloch 1998). Most leaf fossils from Willershausen are brown, but leaves of the genus Fraxinus often show a greenish color (Figs. 1a, 2a) (Straus 1977; Knobloch 1998). Preservation of colors in fossil leaves is a remarkable phenomenon that can be observed only at very few other localities such as Clarkia (Miocene, Idaho, USA) (Smiley and Rember 1985) and Geiseltal (Eocene, Germany) (Weigelt and Noack 1932; Dilcher et al. 1970).

\section{Geological setting}

The Willershausen locality is situated in the western foreland of the Harz Mountains, Germany, about 30 km north of Göttingen. In the former clay pit, laminated clays with a single laminated carbonate horizon of about $30 \mathrm{~cm}$ thickness were exposed. The Upper Pliocene sediments were deposited in a small meromictic lake with anoxic bottom water, representing a sink-hole that was formed by the dissolution of underlying Permian evaporites (Meischner and Paul 1982). During a period of about 300 years, the lake water was alkaline, leading to enhanced carbonate precipitation and to the formation of laminated dolomites in the center of the lake (Meischner and

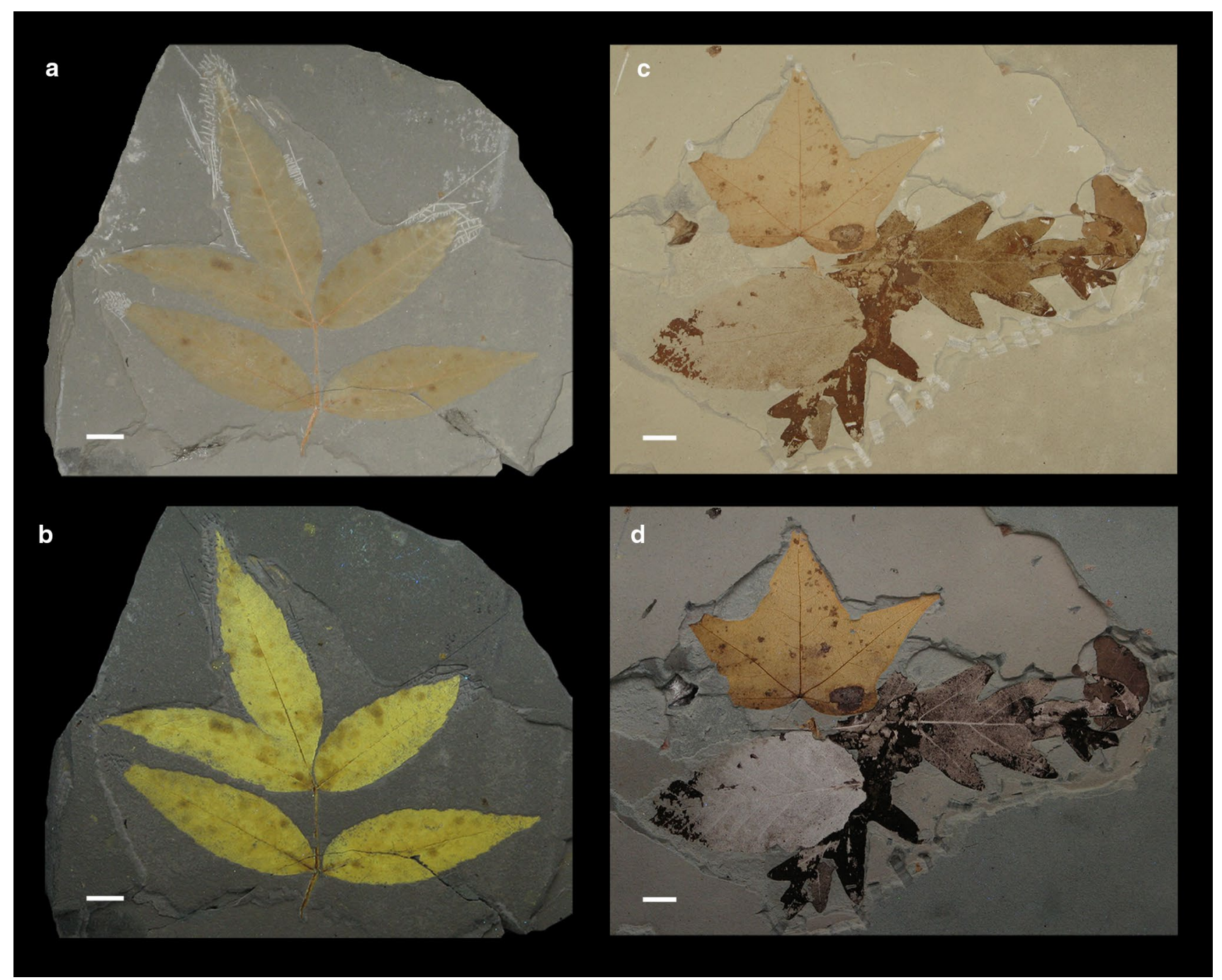

Fig. 1 Fossil leaves from the Pliocene of Willershausen showing UV-light-induced fluorescence. a, b Fraxinus pliocenica, GZG.W.34353. c, d Acer integerrimum, Quercus praeerucifolia, Fagus pliocenica, SMNS-P-P001994-399. Scale, 1 cm. a, c, normal light; b, d, UV-light 


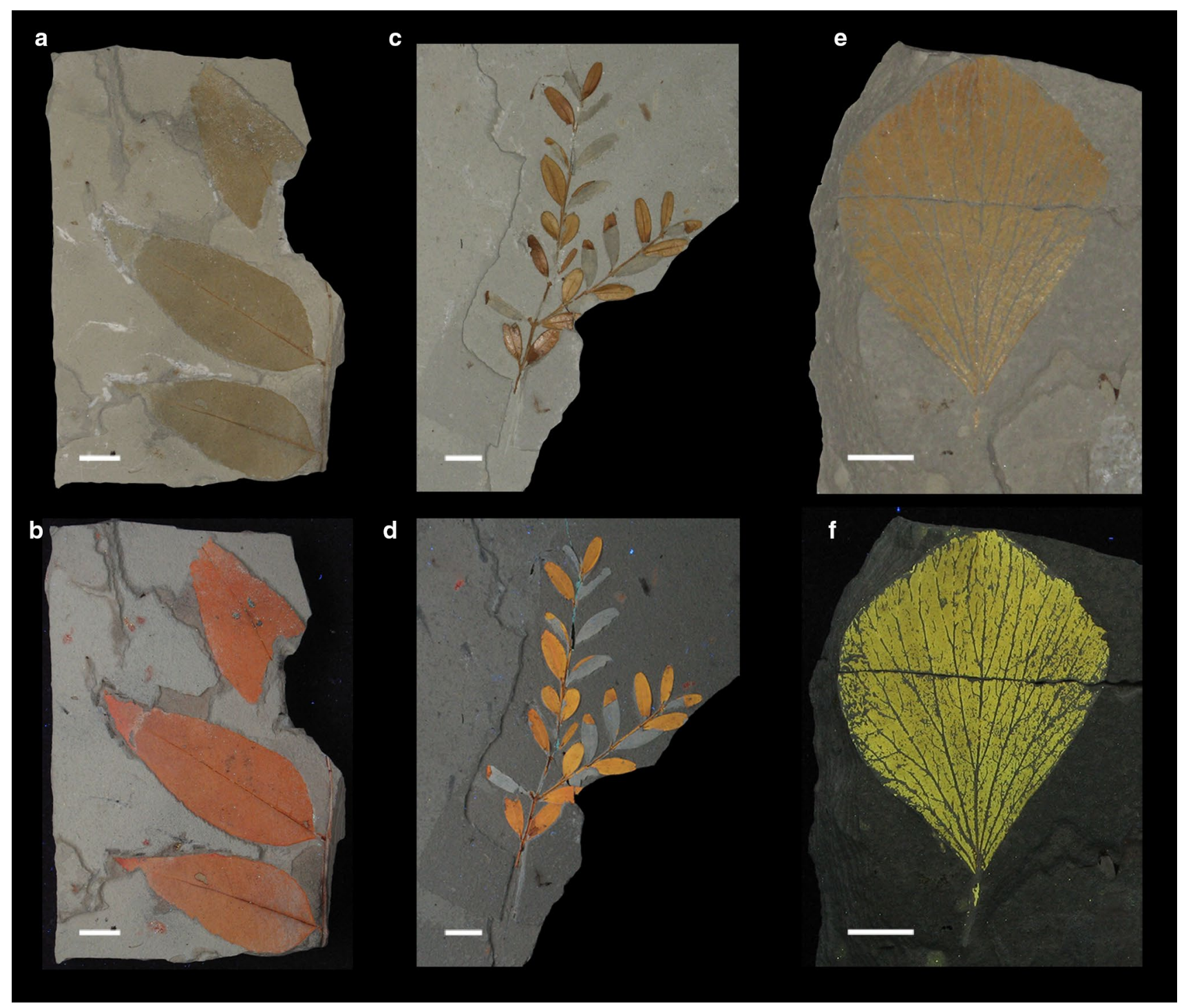

Fig. 2 Fossil leaves from the Pliocene of Willershausen showing UV-light-induced fluorescence. a, b Fraxinus pliocenica, SMNSP-P001994-187. c, d Buxus pliocenica, SMNS-P-P001993-401. e, f Hedera sp., GZG.W.09681. Scale, $1 \mathrm{~cm}$. a, c, e, normal light; b, d, f, UV-light. Exposure time was $2 \mathrm{~s}$ for all UV photographs except $\mathbf{f}$ with an exposure time of $1 \mathrm{~s}$ due to the very intense fluorescence of the fossil
Paul 1982). Almost all fossils from Willershausen have been collected from the carbonate horizon (Briggs et al. 1998). Geochemical analyses of the Willershausen clay revealed the presence of intact sterols and stanols, and of $\beta \beta$ hopanes, indicating that the sediment is very immature, although transformation of phytoplankton chlorophyll(s) to porphyrins is documented (Keely et al. 1994).

\section{Materials and methods}

For the present study, we investigated material from the collections of the Geoscience Centre of the University of Göttingen (GZG) and the State Museum of Natural History Stuttgart (SMNS), representing the two largest collections 
from the Willershausen locality (comprising more than 7500 leaf fossils, Adroit et al. 2018). Only the 12 most common genera of leaves from Willershausen (according to Knobloch 1998) and accessory taxa that showed conspicuous fluorescence were evaluated. Taxonomic assignment of leaves was done according to Straus (e.g., 1930,1952,1992) and Knobloch (1998) who studied the fossil plant assemblage of Willershausen based on leaf gross morphology. Although desirable, a modern revision is not available. For comparison, modern autumnal leaves were collected in the Forest Botanical Garden of the University of Göttingen and were pressed and air-dried at room temperature. UV-light-induced autofluorescence of leaves was documented using a Canon PowerShot A700 digital camera and a Philips TLD 18W/08 UV-A Blacklight Blue Lamp (340-400 nm, emission maximum at $365 \mathrm{~nm}$ ), with a distance of the light source to the fossils of about $15 \mathrm{~cm}$. If not indicated differently, the exposure time for all UV photographs was two seconds. Microscopic fluorescence images and fluorescence emission spectra were obtained using a Zeiss LSM 510 confocal laser scanning microscope equipped with a META spectral detector. Fluorescence emission spectra were measured in the range of 501-704 $\mathrm{nm}$ using a non-destructive laser excitation wavelength of $488 \mathrm{~nm}$.

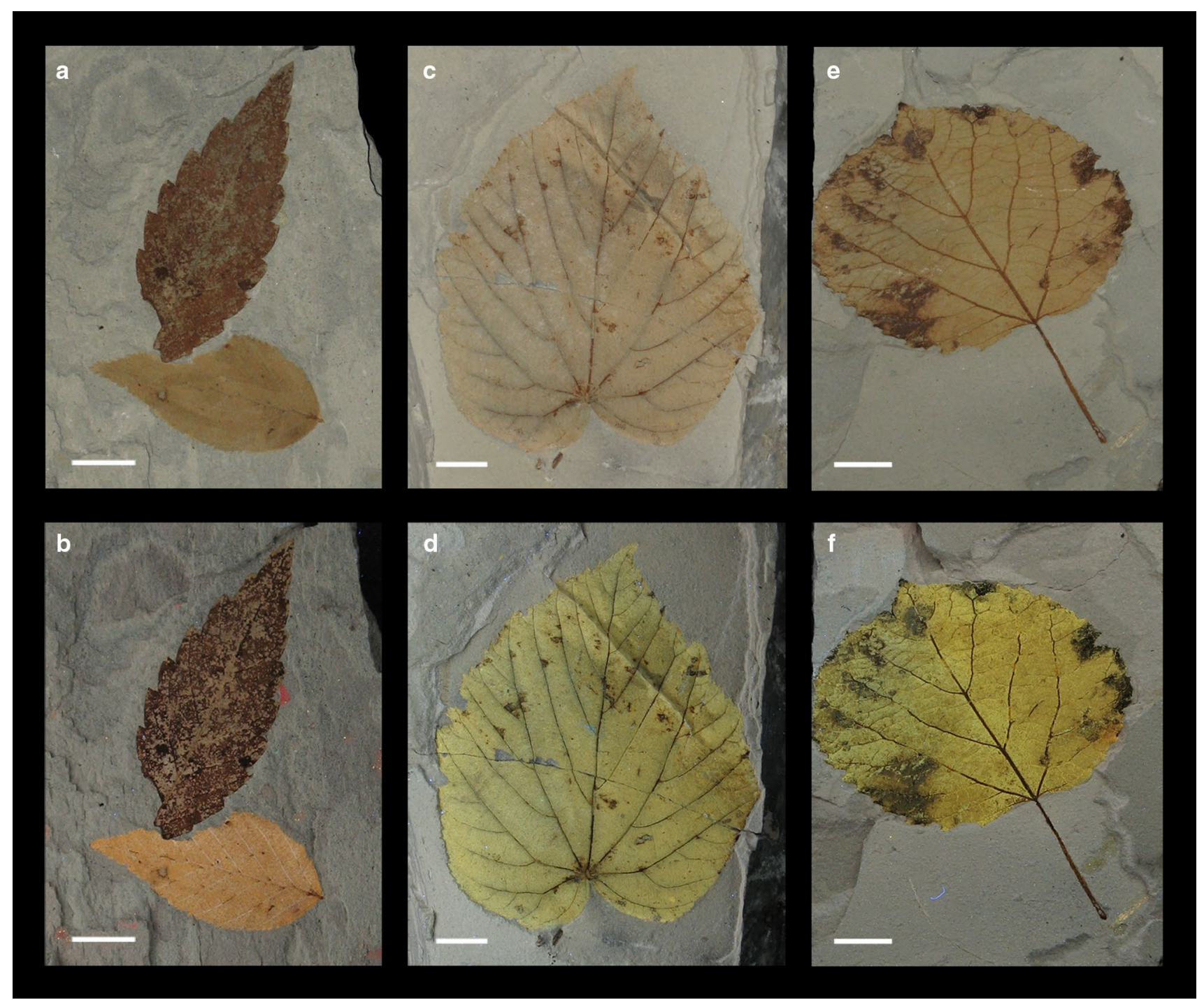

Fig. 3 Fossil leaves from the Pliocene of Willershausen showing UVlight-induced fluorescence. a, b Zelkova zelkovifolia (upper), Carpinus sp. (lower), SMNS-P-P001993-154a. c, d Tilia aff. americana,
SMNS-P-P001520-3. e, f Populus cf. tremula, SMNS-P-P001534-2. Scale, $1 \mathrm{~cm}$. a, c, e, normal light; b, d, f, UV-light 


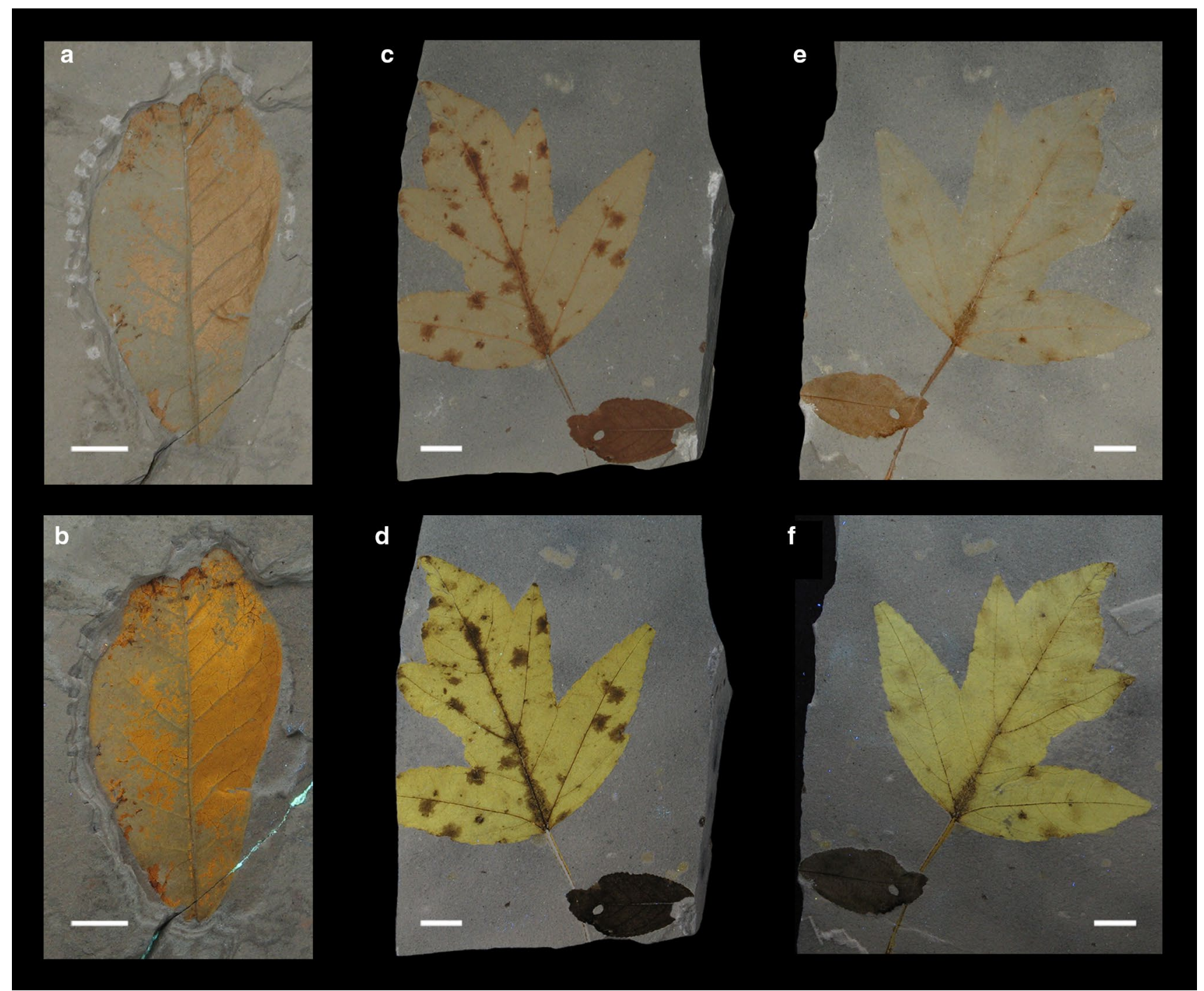

Fig. 4 Fossil leaves from the Pliocene of Willershausen showing UV-light-induced fluorescence. a, b Magnolia sp., SMNS-PP001994-424. c, d Malus pulcherrima, SMNS-P-P001447b-1. e, f

\section{Results and discussion}

Under UV-light, a distinct fluorescence of many well-preserved leaves from Willershausen can be observed with fluorescence colors ranging from green to yellow to red (Figs. 1, 2, 3, 4, 5). The collected data suggest that the occurrence of fluorescence, and to some extent the fluorescence color, is taxon-specific. In some genera fluorescence is relatively common and very distinct (e.g., Acer, Betula, Fraxinus, cf. Magnolia), whereas for other genera generally no or only very weak fluorescence is observed (e.g., Fagus, Quercus, Zelkova) (Table 1). The relationship of fluorescence properties with genera is most obvious in those cases where assemblages of leaves composed of different genera are found on the same slab, i.e., representing
Malus pulcherrima, SMNS-P-P001447a-1 (counter slab of SMNS-PP001447b-1). Scale, 1 cm. a, c, e, normal light; b, d, f, UV-light

specimens preserved under identical conditions of fossilization (Figs. 1d, 3b).

Fluorescence is mainly observed in deciduous taxa, but can be observed in evergreen taxa (Buxus and Hedera) as well (Fig. 2d, f). Several leaves show signs of discoloration, which is also reflected in differences of the fluorescence. An outstanding example is a leaf of Malus pulcherrima with dark non-fluorescent spots, likely caused by lesions and senescence during life-time of the shrub (Fig. 4d). These differences in the fluorescence of evidently discolored leaves indicate that fluorescence of leaves is influenced by lesions and senescence. The impact of autumnal senescence is supported by the observation that generally rather dark-brown colored and non-fluorescent Willershausen taxa like Fagus and Quercus are taxa with modern counterparts (e.g., Fagus 


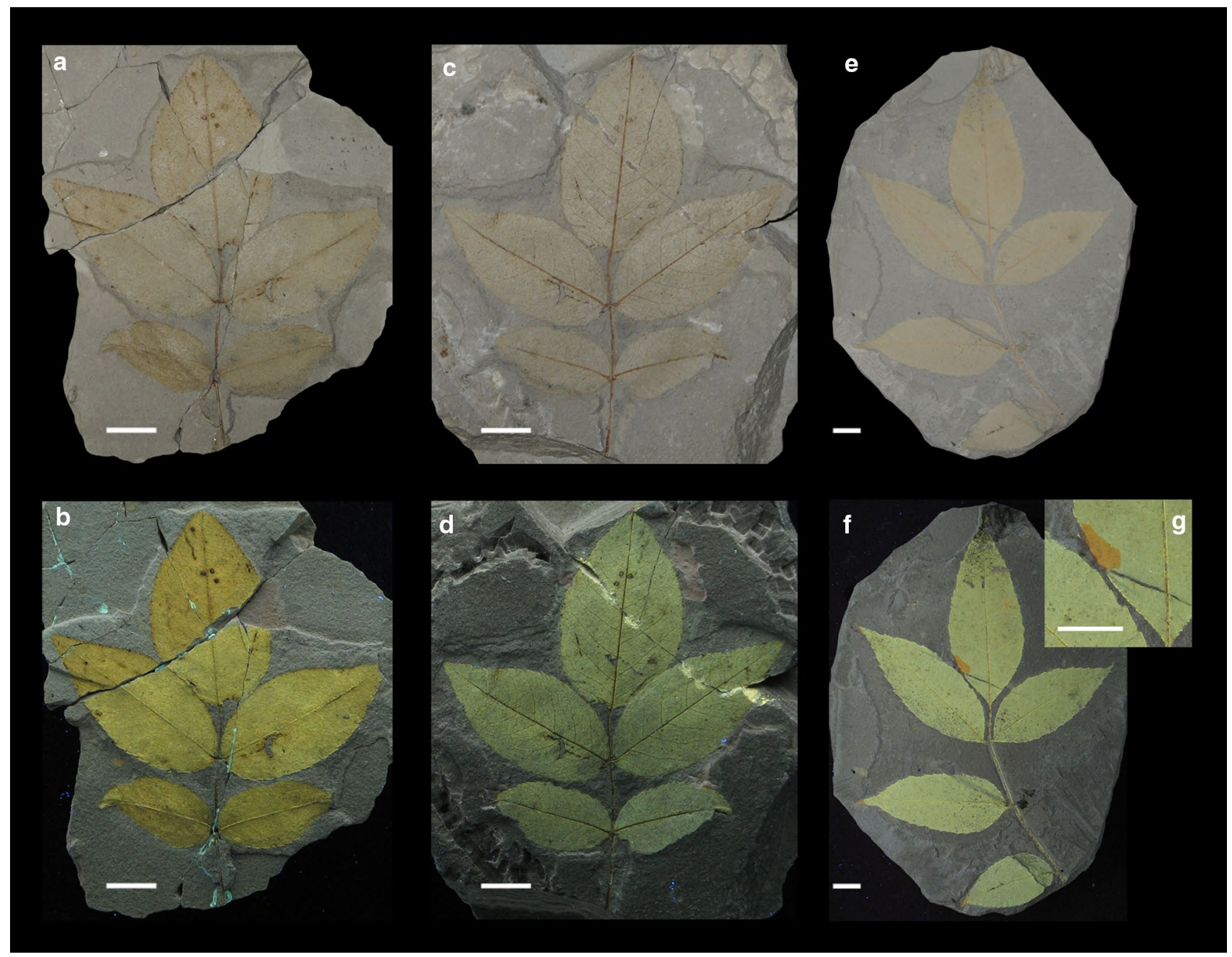

Fig. 5 Fossil leaves from the Pliocene of Willershausen showing UVlight-induced fluorescence. a, b Rosa sp., GZG.W.30595a. c, d Rosa sp., GZG.W.30595b (counter slab of GZG.W.30595a). e, f Fraxi-

sylvatica, Quercus petraea) that show strong discoloration before leaf fall. It is also striking that light-brown colored leaves from Willershausen usually show fluorescence, whereas dark-brown colored leaves of the same genera generally are non-fluorescent (Table 1). However, it should be noted that for most leaf specimens it is usually difficult to distinguish between discoloration by senescence and discoloration by decompositional processes between leaf fall and sedimentation. Assessing the entire collection material of Willershausen leaves, it can be observed that the majority of leaf fossils show no fluorescence and leaves showing fluorescence generally are very well preserved.

Observation of leaves in detail reveals that fluorescence is associated with specific leaf layers and structures. Many leaf compressions from Willershausen are split apart, and in some specimens, fluorescence differs between the leaf material on main slab and counter slab. For example, the nus pliocenica, SMNS-P-P001446. g Detailed view of the specimen depicted in $\mathbf{f}$, showing different fluorescence colors of different leaf layers. Scale, $1 \mathrm{~cm}$. a, c, e, normal light; b, d, f, g, UV-light

dark spots of the Malus pulcherrima specimen cited above (Fig. 4d) are only faintly seen on the counter slab which shows a yellow fluorescence throughout (Fig. 4f). Some specimens even show different fluorescence colors for different layers of a leaf. The upper leaf layers (in abaxial view) on the main slab of a Rosa specimen show yellow fluorescence (Fig. 5b), whereas the lower layers (in adaxial view) on the counter slab show green fluorescence (Fig. 5d). Differences in the fluorescence colors are most obvious in specimens of Fraxinus with examples showing yellow to red or green fluorescence (Figs. 1b, 2b, 5f). In some specimens of Fraxinus, the remaining part of an overlaying layer is preserved on the same slab, such as in a specimen that shows green fluorescence of the lower leaf layers and orange fluorescence of the remaining parts of the upper leaf layers (Fig. 5f, g). Using confocal laser scanning microscopy (CLSM), leaves were studied in further detail (Fig. 6). CLSM fluorescence 
Table 1 Typical fluorescence properties and normal light color of fossil leaves from Willershausen

\begin{tabular}{llll}
\hline Family & Genus & Normal light color & Fluorescence color $^{\mathrm{a}}$ \\
\hline Aceraceae & Acer & Light-brown/dark-brown & Orange/- \\
Araliaceae & Hedera $^{*}$ & Brown & Yellow \\
Betulaceae & Betula & Light-brown & Yellow to orange \\
& Carpinus & Light-brown & Yellow to orange \\
Buxaceae & Buxus* & Brown & Orange \\
Fagaceae & Fagus & Brown to dark-brown & - \\
& Quercus & Brown to dark-brown & - \\
Magnoliaceae & cf. Magnolia & Light-brown to brown & Orange \\
Oleaceae & Fraxinus & Greenish & Yellow to red \\
Rosaceae & Malus & Light-brown & Yellow \\
& Rosa* & Light-brown & Yellow \\
Salicaceae & Populus & Light-brown/dark-brown & Yellow/- \\
Tiliaceae & Tilia & Light-brown/dark-brown & Yellow/- \\
Ulmaceae & Ulmus & Brown to dark-brown & - \\
& Zelkova & Brown to dark-brown & - \\
\hline
\end{tabular}

Listed genera represent the 12 most common genera of leaves from Willershausen (according to Knobloch 1998 ) except those indicated $(*)$ representing accessory taxa that showed conspicuous fluorescence; - indicates no fluorescence observed

${ }^{\mathrm{a}} \mathrm{UV}$-light excitation

${ }^{b}$ In some specimens, green fluorescence of lower leaf layer images show cell structures, but no stomata, suggesting that mainly the mesophyll or upper epidermis is exposed in the investigated fossil leaves. Moreover, it was possible to measure fluorescence emission spectra of areas with differences in their fluorescence properties. Typically, a broad fluorescence emission with maxima in the range of 540 to $580 \mathrm{~nm}$ is observed for green- to yellow-fluorescent leaves, whereas red-fluorescent leaves of Fraxinus show an additional distinct emission at about $650 \mathrm{~nm}$ (Fig. 6a-c). Both fluorescence emissions were studied in a specimen of Fraxinus with a yellow-fluorescent leaf layer and partially remaining overlaying red-fluorescent leaf layer (Fig. 6c).

Comparison of fluorescence properties of fossil leaves from Willershausen with those of present-day leaves show remarkable similarities. After several days of drying, many present-day autumnal leaves that initially showed only weak fluorescence revealed a distinct fluorescence (e.g., yellowish fluorescence of Acer pseudoplatanus, Betula pendula). By contrast, leaves that already exhibited strong brown discoloration when collected (e.g., Quercus petraea, Fagus sylvatica) showed no fluorescence as in the case of the fossil species. Moreover, corresponding to the distribution of pigments within leaf structures, fluorescence of present-day leaves is also associated with specific layers with often more pronounced fluorescence of the abaxial (lower) sides of the leaf.

In living plants many different fluorophores are known to occur. Blue to green fluorescence is mainly caused by phenolic compounds and red fluorescence mainly by chlorophylls (García-Plazaola et al. 2015). It has been shown that the green color of fossil leaves from the Eocene of Geiseltal is due to the chlorophyll $a$ degradation product methyl pheophorbide $a$ (Dilcher et al. 1970). It is therefore reasonable to assume that the red fluorescence (distinct fluorescence emission maximum at about $650 \mathrm{~nm}$ ) of greencolored Fraxinus leaves from Willershausen (Fig. 6c) is due to chlorophyll degradation products. This is also supported by comparison with the fluorescence emission spectrum of a still green-colored present-day autumnal Fraxinus leaf showing a distinct chlorophyll fluorescence emission at about $680 \mathrm{~nm}$ (Fig. 6d). In modern senescent leaves fluorescence is caused by colorless chlorophyll catabolites (phyllobilins) (Kräutler 2016) and phenolic compounds. Flavonoids, belonging to the latter group, are also known from fossil leaves (Niklas and Giannasi 1977). The broad fluorescence emission in the range of 540-580 $\mathrm{nm}$ in leaves from Willershausen may be explained by similar compounds. However, this can only be verified by detailed and destructive chemical analysis, which would be beyond the scope of the present study.

It is remarkable to observe a wide range of fluorescence colors in the leaf fossils from a single locality. Traditionally, different fluorescence colors of fossil plant remains (from different localities) are attributed to differences in diagenesis. With increasing thermal maturity, fluorescence intensity decreases, accompanied by a shift of the fluorescence emission maximum to the red, finally followed by the extinction of fluorescence (Van Gijzel 1967, 1977; Teichmüller 
Fig. 6 CLSM images and fluorescence emission spectra of fossil leaves from Willershausen and present-day leaf. a Hedera sp., Pliocene, Willershausen, GZG.W.09681, yellow-fluorescent leaf. b Rosa sp., Pliocene, Willershausen, GZG.W.30595b, green-fluorescent leaf. c

Fraxinus sp., Pliocene, Willershausen, GZG.W.20213, image shows border between yellow-fluorescent leaf layer and overlaying red-fluorescent leaf layer. d Fraxinus excelsior, modern green-colored autumnal leaf. Spectra are from indicated spots in the images; blue spectra are from the sediment from areas where the fossil material is broken out

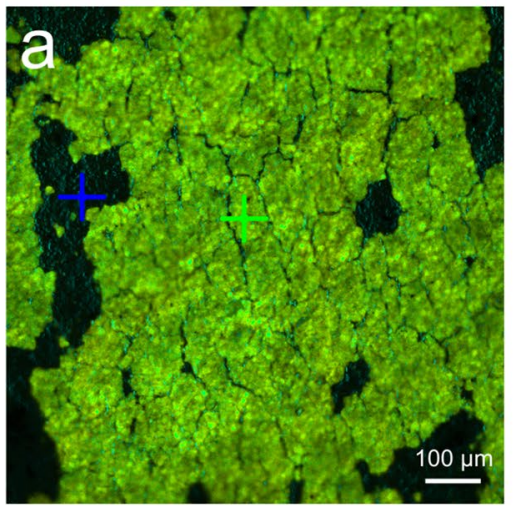

Intensity
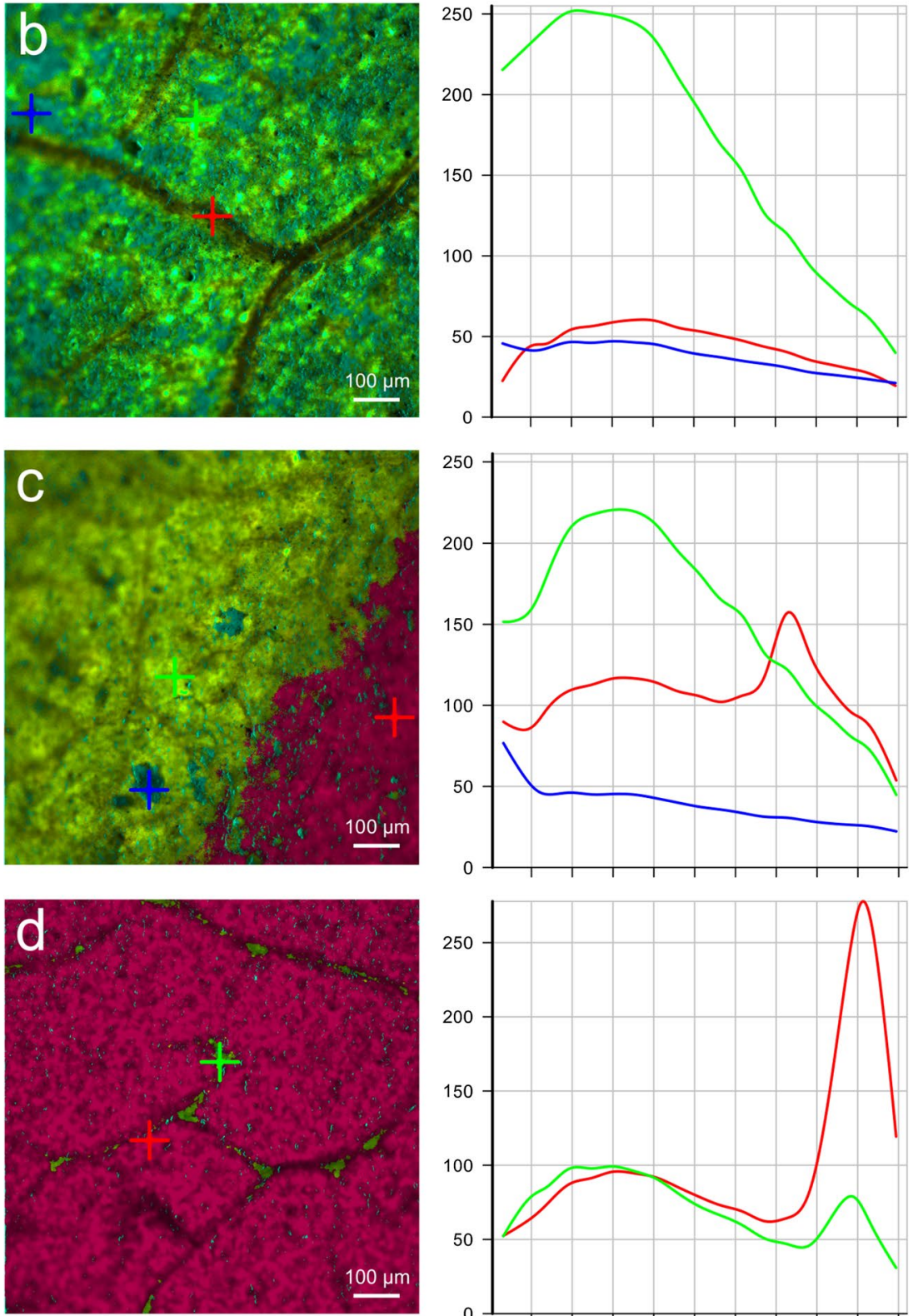
and Wolf 1977). However, in this study we demonstrate that different fluorescence colors, related to different groups of fluorophores, can be taxon- and senescence-specific, and can occur unrelated to diagenesis. A prerequisite for this exceptional record is that, as in the case of Willershausen, sediments were not deeply buried and the organic matter has remained very immature.

The specific conditions at the Willershausen lake with anoxic and alkaline lake water (Meischner and Paul 1982) obviously account for the exceptional preservation of the leaf fossils. An anoxic environment affected by alkaline karstic waters is also documented for the green-colored leaves from the Eocene brown coal of the Geiseltal (Weigelt and Noack 1932) that show different fluorescence colors as well (red fluorescence of olive-green leaves and yellow or green fluorescence of yellow-green leaves, own observations). Taxon-related fluorescence has also been observed for the Eocene Messel flora (Wilde 1989) and the Miocene Clarkia flora (e.g., yellow fluorescence of Lithocarpus leaves, own observations).

\section{Conclusions}

Imaging and measurement of UV-light-induced fluorescence allow for the non-destructive and highly sensitive analysis of fossil plant substances. Our observations strongly suggest that the fluorescence differences in the leaves from Willershausen indicate chemical differences of the fossil organic matter. These differences likely are caused by the taxondependent breakdown of organic compounds during senescence via catabolism and subsequent changes between leaf fall and sedimentation. Diagenetic changes cannot explain different fluorescence properties of various leaf taxa preserved under identical conditions of fossilization. Since taxonomic assignment based on isolated leaf fossils is often difficult due to significant morphological variations within leaf taxa, the fluorescence properties of well-preserved leaf fossils from Willershausen might be used for taxonomic purposes, supplementary to morphological characteristics. Furthermore, CLSM enables the localization of fluorophores up to the cellular level in the fossilized leaf tissue. By measuring of fluorescence emission spectra, different classes of fluorophores can be distinguished. Preliminary observations suggest that taxon- and senescence-related fluorescence of well-preserved fossil leaves may also be studied at a number of other fossil Lagerstätten.

Acknowledgements We thank Johanna Eder (SMNS) and Benjamin Bomfleur (University of Münster) for discussion and helpful comments on an earlier version of the manuscript. Furthermore, we thank Günter Schweigert (SMNS), Anita Roth-Nebelsick (SMNS), Mike Reich (formerly GZG), Alexander Gehler (GZG), and Stephan Schultka (Museum für Naturkunde Berlin) for access to collection material and
William Rember for help with collecting fossil leaves at Clarkia. We are also grateful to Alexander Gehler, Mike Reich (Editor-in-Chief), and Joachim Reitner (Associated Editor) for their helpful comments and suggestions. This work was supported by the Deutsche Forschungs gemeinschaft (WO 1491/4-2 to K.W.).

Funding Open Access funding enabled and organized by Projekt DEAL.

Open Access This article is licensed under a Creative Commons Attribution 4.0 International License, which permits use, sharing, adaptation, distribution and reproduction in any medium or format, as long as you give appropriate credit to the original author(s) and the source, provide a link to the Creative Commons licence, and indicate if changes were made. The images or other third party material in this article are included in the article's Creative Commons licence, unless indicated otherwise in a credit line to the material. If material is not included in the article's Creative Commons licence and your intended use is not permitted by statutory regulation or exceeds the permitted use, you will need to obtain permission directly from the copyright holder. To view a copy of this licence, visit http://creativecommons.org/licenses/by/4.0/.

\section{References}

Adroit, B., V. Girard, L. Kunzmann, J.-F. Terral, and T. Wappler. 2018. Plant-insect interactions patterns in three European paleoforests of the late-Neogene early-Quaternary. PeerJ 6: e5075. https://doi. org/10.7717/peerj.5075.

Briggs, D.E.G., B.A. Stankiewicz, D. Meischner, A. Bierstedt, and R.P. Evershed. 1998. Taphonomy of arthropod cuticles from Pliocene lake sediments, Willershausen, Germany. Palaios 13: 386-394.

Dilcher, D.L., R.J. Pavlick, and J. Mitchell. 1970. Chlorophyll derivatives in Middle Eocene sediments. Science 168: 1447-1449.

Elgorriaga, A., I.H. Escapa, and N.R. Cúneo. 2019. Relictual Lepidopteris (Peltaspermales) from the Early Jurassic Cañadón Asfalto Formation, Patagonia, Argentina. International Journal of Plant Sciences 180: 578-596.

Ferguson, D.K., and E. Knobloch. 1998. A fresh look at the rich assemblage from the Pliocene sink-hole of Willershausen, Germany. Review of Palaeobotany and Palynology 101: 271-286.

Friedrich, W.L., and F. Schaarschmidt. 1977. Zwei- und dreidimensionale Fluoreszenzaufnahmen von fossilen Pflanzen. Courier Forschungsinstitut Senckenberg 24: 31-49.

García-Plazaola, J.I., B. Fernández-Marín, S.O. Duke, A. Hernández, F. López-Arbeloa, and J.M. Becerril. 2015. Autofluorescence: Biological functions and technical applications. Plant Science 236: $136-145$.

Keely, B.J., P.G. Harris, B.N. Popp, J.M. Hayes, D. Meischner, and J.R. Maxwell. 1994. Porphyrin and chlorin distributions in a Late Pliocene lacustrine sediment. Geochimica et Cosmochimica Acta 58: 3691-3701.

Kerp, H. 1990. The study of fossil gymnosperms by means of cuticular analysis. Palaios 5: 548-569.

Kerp, H., and B. Bomfleur. 2011. Photography of plant fossils-New techniques, old tricks. Review of Palaeobotany and Palynology 166: $117-151$.

Knobloch, E. 1998. Der Pliozäne Laubwald von Willershausen am Harz (Mitteleuropa). Documenta Naturae 120: 1-302.

Kräutler, B. 2016. Breakdown of chlorophyll in higher plants-Phyllobilins as abundant, yet hardly visible signs of ripening, senescence, and cell death. Angewandte Chemie International Edition 55: 4882-4907. 
Mai, D.H. 1995. Tertiäre Vegetationsgeschichte Europas. Methoden und Ergebnisse. Jena: Fischer.

Meischner, D., and J. Paul. 1982. Die pliozäne Fossilfundstätte Naturdenkmal Tongrube Willershausen. Courier Forschungsinstitut Senckenberg 56: 147-152.

Meyer, H.W. 2003. The Fossils of Florissant. Washington: Smithsonian Books.

Niklas, K.J., and D.E. Giannasi. 1977. Flavonoids and other chemical constituents of fossil Miocene Zelkova (Ulmaceae). Science 196: $877-878$

Rietschel, S., and G. Storch. 1974. Außergewöhnlich erhaltene Waldmäuse (Apodemus atavus Heller 1936) aus dem Ober-Pliozän von Willershausen am Harz. Senckenbergiana Lethaea 54: 491-519.

Schaarschmidt, F. 1982. Präparation und Untersuchung der Eozänen Pflanzenfossilien von Messel bei Darmstadt. Courier Forschungsinstitut Senckenberg 56: 59-77.

Schaarschmidt, F. 1988. Der Wald, fossile Pflanzen als Zeugen eines warmen Klimas. In Messel - Ein Schaufenster in die Geschichte der Erde und des Lebens, eds. S. Schaal and W. Ziegler, 27-52. Frankfurt am Main: Waldemar Kramer.

Schmidt, H. 1939. Der vorzeitliche 'Park' von Willershausen. Mitteilungen der Deutschen Dendrologischen Gesellschaft 52: 143-146.

Smiley, C.J., and W.C. Rember. 1985. Composition of the Miocene Clarkia flora. In Late Cenozoic History of the Pacific Northwest, ed. C.J. Smiley, 95-112. San Francisco: American Association for the Advancement of Science.

Spinar, Z.V. 1980. Fossile Raniden aus dem oberen Pliozän von Willershausen (Niedersachsen). Stuttgarter Beiträge zur Naturkunde B 53: $1-53$.

Straus, A. 1930. Dikotyle Pflanzenreste aus dem Oberpliozän von Willershausen (Kreis Osterode, Harz) 1. Jahrbuch der Preussischen Geologischen Landesanstalt 51(1): 302-336.
Straus, A. 1952. Beiträge zur Pliocänflora von Willershausen III. Die niederen Pflanzengruppen bis zu den Gymnospermen. Palaeontographica B 93(1-3): 1-44.

Straus, A. 1969. Beiträge zur Kenntnis der Pliozänflora von Willershausen (VI). Die Gattung Buxus. Argumenta Palaeobotanica 3: $57-64$.

Straus, A. 1977. Gallen, Minen und andere Fraßspuren im Pliokän von Willershausen am Harz. Verhandlungen des Botanischen Vereins der Provinz Brandenburg 113: 41-80.

Straus, A. 1992. Die oberpliozäne Flora von Willershausen am Harz. Berichte der Naturhistorischen Gesellschaft Hannover 134: 7-115.

Teichmüller, M., and M. Wolf. 1977. Application of fluorescence microscopy in coal petrology and oil exploration. Journal of Microscopy 109: 49-73.

Van Gijzel, P. 1967. Palynology and fluorescence microscopy. Review of Palaeobotany and Palynology 2: 49-79.

Van Gijzel, P. 1977. Die Fluoreszenz-Mikroskopie einiger Pflanzenfossilien. Courier Forschungsinstitut Senckenberg 24: 92-100.

Weigelt, J., and K. Noack. 1932. Über Reste von Blattfarbstoffen in Blättern aus der Geiseltal-Braunkohle (Mitteleocän). Nova Acta Leopoldina, Neue Folge 1: 87-96.

Westphal, F. 1967. Erster Nachweis des Riesensalamanders (Andrias, Urodela, Amphibia) im europäischen Jungpliozän. Neues Jahrbuch für Geologie und Paläontologie, Monatshefte 1967: 67-73.

Wilde, V. 1989. Untersuchungen zur Systematik der Blattreste aus dem Mitteleozän der Grube Messel bei Darmstadt (Hessen, Bundesrepublik Deutschland). Courier Forschungsinstitut Senckenberg 115: 1-213. 